\title{
Pathogenesis and management of herpes simplex virus keratitis
}

\begin{abstract}
Herpes simplex keratitis (HSK) remains a common cause of unilateral corneal disease. Despite intense research over three decades, the mainstay of therapy continues to be topical and, more recently, systemic acyclovir plus topical corticosteroid in some cases. There is increasing recognition that HSK after keratoplasty can occur not only as a result of recurrence in patients with HSK, but also in patients with other primary diagnoses as a result of activation of $\mathrm{HSV}$ in the host, or by transmission of virus in the donor tissue. Eye (2003) 17, 919-922. doi:10.1038/ sj.eye. 6700564
\end{abstract}

Keywords: herpes simplex virus; keratitis; transplantation

\section{Introduction}

Despite 20 years of intensive research into herpes simplex virus keratitis (HSK) and substantial progress in understanding particularly the virology of herpes simplex virus (HSV), the management of this condition continues to be challenging. Although in the author's impression, HSK is less of a burden than it was, it remains a leading cause of unilateral blindness principally as a result of its chronicity. An estimated 50000 new or recurrent cases are seen each year in the USA. ${ }^{1}$ This paper reviews some aspects of the pathogenesis and management of HSK. These include routes of virus to the eye, host and virus factors that influence the response in the eye, use of topical and systemic antiviral agents, and aspects of corneal transplantation.

\section{Pathogenesis}

If it is the strategy of the virus to infect the majority of the population, then it is an extraordinarily successful pathogen and one that is essentially benign. Involvement of the brain or eye is relatively rare; severe cases of encephalitis or keratitis must surely be seen as aberrations as they serve the virus poorly. They occur, however, as a consequence of a key property namely the virus' ability to establish latent infection not only in neurones supplying the lips, but also in a number of other sites within the nervous system that are reached during primary infection. $^{2}$

\section{How does virus reach the eye?}

Primary infection by HSV generally occurs in childhood after contact with infected lesions or saliva. Where symptomatic, infection results in oropharyngeal features manifest as HSV infection in only $1-6 \%$ of cases $^{3}$ and the eye is rarely involved. It is from the principal location of the trigeminal ganglion that virus is released to result in herpes labialis, a phenomenon that can occur repeatedly throughout the lifetime of some individuals.

Initial ocular episodes, classically as unilateral dendritic ulceration, typically occur much later in life and are then characteristically followed by recurrence and in some cases progressive visual impairment. At an overall prevalence of 149 cases per 100000 person years, ocular manifestations afflict less than $1 \%$ of those exposed to the virus. If a first episode of keratitis results from reactivation of virus in the trigeminal ganglion, it has been shown that it may have reached there at the time of nonocular primary infection. ${ }^{4}$ Thus when the virus first infects the cornea, it has probably arrived from within via the terminal branches of the ophthalmic division of the trigeminal nerve. Occasionally, a first episode results in stromal disease and even anterior uveitis. Once an initial lesion has developed, it is possible that virus may persist in the cornea particularly if virus has entered the stroma.
Department of Ophthalmology

Manchester Royal Eye Hospital

Manchester, UK

Correspondence: A Tullo

Department of

Ophthalmology

Manchester Royal Eye

Hospital

Oxford Road

Manchester M13 9WH, UK

Tel: + 441612765522

Fax: +441612726618

E-mail: andrew.tullo@

cmmc.nhs.uk

Received: 28 February 2003 Accepted in revised form: 28 February 2003 


\section{What are the influences on corneal infection?}

There is clinical and experimental evidence to suggest that some virus strains are more likely to cause severe disease than others. ${ }^{5,6}$ Likewise, host factors may also play an independent role. It is of interest that while most published series on HSK show a male preponderance, ${ }^{7}$ this is not always reflected in the male : female distribution at keratoplasty suggesting that once acquired it is more likely to be severe in females. Recent experimental evidence has shown the influence of gender in mice. ${ }^{8}$ HSK during immunosuppression after organ transplantation may be more common and severe and this was expected to be true in AIDS. However, a prospective study on this aspect suggests this is not necessarily so. ${ }^{9}$ What remains undoubtedly true is the adverse effects of inappropriate topical steroids especially at the epithelial stage of keratitis and perhaps a tendency for the use of steroids too frequently or that are too potent at the stromal stage. Nevertheless, the HEDS studies have shown definitively that some steroids are indicated and effective in some cases of stromal disease. ${ }^{10}$

\section{What are the consequences of corneal infection?}

Much attention has been paid to the events in the cornea that occur once infection has been established. ${ }^{11-15}$ This has necessarily centred on animal experimentation, which, while yielding much useful information, can only achieve limited simulation of the situation in man. This applies to virus strain, size of cornea, for example, in the mouse, and in particular the difficulty in reproducing the chronic indolent process characterised by spontaneous recurrence, which leads to visual impairment over many years. Although little data have emerged that have yet modified current treatment strategies, there remains the promise that this will happen. A much improved understanding on the cellular events in the cornea has emerged, in particular the targeting of inflammatory cells, and how large numbers of cellular proteins are involved with viral activation. These include cytokines such as IL-6, transcription factors, growth factors, and cyclooxygenase. ${ }^{16-18}$ Now microarray analysis is opening up new areas of investigation as to which genes are involved in acute and latent infection. ${ }^{19}$ One of the as yet unresolved questions is the precise state of the virus in different parts of the cornea and at different times during keratitis and indeed in the trigeminal ganglion in patients with keratitis. ${ }^{20}$ An often overlooked consequence of HSK is reduction in tearing that follows hypoaesthesia. ${ }^{21}$

\section{Management}

A more rational approach to treatment has been facilitated by detailed classification of the various manifestations of anterior segment involvement by HSV. $^{22,23}$ The HEDS publications have shown clearly that steroids used appropriately have an important part to play in the management of stromal keratitis. ${ }^{10}$ The evaluation was carried out on a reducing regime of $1 \%$ and then $0.125 \%$ prednisolone phosphate indicating that weak steroid is effective with minimal treatment failure. The HEDS publications also report on the place of oral acyclovir for treatment and prophylaxis, ${ }^{24-26}$ which has set the scene for its increased use today including the management of children. ${ }^{27}$

Although topical acyclovir is not routinely used in the USA, it is the first-line antiviral treatment in Europe for epithelial and stromal disease. This agent is converted to its active form by viral thymidine kinase and therefore only becomes active as a binder of viral DNA polymerase in infected cells. ${ }^{28}$ The advent of acyclovir has been a major therapeutic advance not only for the elegance of its mode of action and its efficacy, but also for the rarity of significant toxicity. Trifluorothymidine is a useful additional agent particularly in stromal disease where penetration is good. It is a nucleoside with an abnormal base that cannot be read by viral enzymes thus interfering with replication. ${ }^{29}$

Keratoplasty has an important part to play in the replacement of permanently opacified cornea. As HSK is almost invariably unilateral, it has been argued that even successful grafting has limited advantages for the patient. ${ }^{30}$ However, notwithstanding the important qualification that much of the published data are based on clinical rather than laboratory diagnosis, there is a large literature on HSK and corneal transplantation. ${ }^{31}$ Interest in this form of management has been rekindled by the recognition of the relatively poor outcome of surgery, an evidence base for the use of systemic antiviral agents, ${ }^{32}$ and the recent development of deep lamellar keratoplasty. Although HSK remains a significant indication for transplantation opportunities to optimize, postoperative management is not always taken. In known or presumptive cases of HSK, tissue following surgery should be subjected to close scrutiny in particular by PCR and immunohistochemistry, which can reveal useful information on the need for continuing antiviral prophylaxis. ${ }^{33}$

\section{Herpetic keratitis following corneal transplantation}

The most likely situation to find viral infection after keratoplasty is when recipient virus responsible for disease requiring surgery produces recrudescence. This is a well-recognised postsurgical complication occurring in up to $25 \%{ }^{34}$ in the first year. Prophylaxis against this can be expected with the use of systemic acyclovir for 6 months or more. ${ }^{35}$ The optimal dosage and the duration 
of treatment are not yet established and the results of a randomised prospective controlled study from Rotterdam are awaited with interest.

There are however a number of other circumstances in which HSV may result in disease following keratoplasty (Table 1). ${ }^{36}$ The most likely explanation for this is transmission through transplantation in apparently healthy normal corneas, which has been recently reported by a number of authors and should now be recognised as a cause of primary graft failure. ${ }^{37-40}$ Furthermore, HSV is a cause of endothelial necrosis and even dendritic keratitis in organ culture. ${ }^{41,42}$ Added to this is the recognition that viral DNA is not infrequently found in corneas removed at keratoplasty from patients with other diagnoses ${ }^{33}$ and intriguingly Remeijer et al ${ }^{43}$ have recently shown by genotyping that on occasion the virus isolated from cases of 'recurrence' after

keratoplasty for HSK differs from the previously isolated recipient strain (Figure 1).

The unanswered question put at the beginning of this paper should perhaps be reposed. If there is evidence of

Table 1 Circumstances in which post keratoplasty infection with HSV can occur

\begin{tabular}{ll}
\hline $\begin{array}{l}\text { Diagnosis requiring } \\
\text { keratoplasty }\end{array}$ & $\begin{array}{l}\text { Herpes simplex infection } \\
\text { following keratoplasty }\end{array}$ \\
\hline Herpes simplex keratitis & $\begin{array}{l}\text { Recurrence } \\
\text { 'Superinfection' by another } \\
\text { virus strain }\end{array}$ \\
Other diagnoses & $\begin{array}{l}\text { Primary infection } \\
\text { Activation of latent infection } \\
\text { in the host } \\
\text { Transmission of HSV in the donor }\end{array}$
\end{tabular}

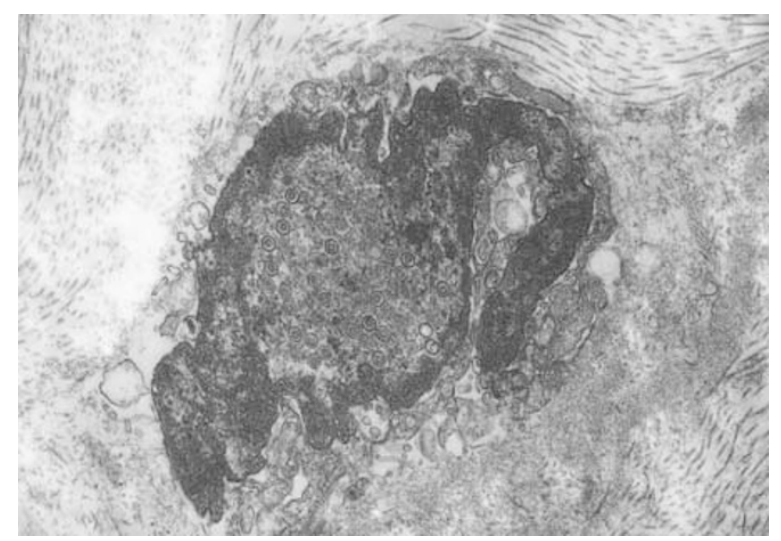

Figure 1 Herpes simplex virus within the nucleus of a cell (probably a keratocyte) showing margination of chromatin and numerous virus particles. ${ }^{44}$ The specimen was removed from a patient with HSK at keratoplasty and placed in culture for 21 days (electron microscopy $\times 40000$ magnification). the unexpected presence of HSV in the normal human cornea and in the presence of other disease, why are some patients unlucky enough to get HSK?

\section{References}

1 Liesegang TJ. Herpes simplex virus epidemiology and ocular importance. Cornea 2001; 20: 1-13.

2 Labetoulle M, Kucera P, Ugolini G, Lafay F, Frau E, Offret H et al. Neuronal propagation of HSV 1 from the oral mucosa to the eye. Invest Ophthalmol Vis Sci 2000; 41: 2600-2606.

3 Umene K, Sakaoke H. Evolution of herpes simplex type 1 under herpes virus evolutionary processes. Arch Virol 1999; 144: 637-656.

4 Tullo AB, Shimeld C, Hill TJ, Blyth WA, Easty DL. Spread of virus and distribution of latent infection following ocular herpes simplex in non-immune and immune mice. J Gen Virol 1982; 63: 95-101.

5 Tullo AB, Coupes D, Klapper PE, Cleator GM, Chitkara D. Analysis of glycoproteins expressed by isolates of herpes simplex virus causing different forms of keratitis in man. Curr Eye Res 1987; 6: 33-38.

6 Zheng X, Silverman RH, Zhou A, Goto T, Kwon BS, Kaufman HE et al. Increased severity of HSV 1 keratitis and mortality in mice lacking the 2-5A-dependent RNAse L gene. Invest Ophthalmol Vis Sci 2001; 42: 120-126.

7 Leisegang TJ, Melton III LJ, Daly PJ, Ilstrup DM. Epidemiology of ocular herpes simplex. Incidence in Rochester, Minn, 1950 through 1982. Arch Ophthalmol 1989; 107: 1155-1159.

8 Han X, Lundberg P, Tanamachi B, Openshaw H, Longmate J, Cantin E. Gender influences herpes simplex virus type 1 infection in normal and gamma interferon-mutant mice. J Virol 2001; 75: 3048-3052.

9 Hodge WG, Margolis TP. Herpes simplex virus keratitis among patients who are positive or negative for human immunodeficiency virus. Ophthalmology 1997; 104: 120-124.

10 Wilhelmus KR, Gee L, Hauk WW et al. Herpetic eye disease study. A controlled trial of topical corticosteroids for herpes simplex stromal keratitis. Ophthalmology 1994; 101: 1883-1895.

11 Dana MR, Qian Y, Hamrah P. Twenty-five-year panorama of corneal immunology. Cornea 2000; 19: 625-643.

12 Hendricks RL. An immunologist's view of herpes simplex keratitis: Thygeson Lecture 1996. Cornea 1997; 16: 503-506.

13 Pepose JS. Herpes simplex keratitis: role of viral infection versus immune response. Surv Ophthalmol 1991; 35: 345-352.

14 Nicholls SM, Shimeld C, Easty DL, Hill TJ. Recurrent HSV after corneal transplantation in the rat. Invest Ophthalmol Vis Sci 1996; 37: 425-435.

15 Shimeld C, Whiteland JL, Nicholls SM, Easty DL, Hill TJ. Immune cell infiltration in corneas of mice with recurrent herpes simplex. J Gen Virol 1996; 77: 977-985.

16 Stumpf TA, Shimeld C, Easty DL, Hill TJ. Cytokine production in a murine model of recurrent herpetic stromal keratitis. Invest Ophthalmol Vis Sci. 2001; 42: 372-378.

17 Norose K, Yano A, Zhang X-M, Blankenhorn E, Heber-Katz E. Mapping of genes involved in murine herpes simplex virus keratitis: identification of genes and their modifiers. J Virol 2002; 76: 3502-3510.

18 Fenton RR, Molesworth-Kenyon S, Oakes JE, Lausch RN. Linkage of IL-6 with neutrophil chemoattractant expression 
in virus-induced ocular inflammation. Invest Ophthalmol Vis Sci 2002; 43: 737-743.

19 Higaki S, Geghardt BM, Lukiw WJ, Thompson HW, Hill JM. Effect of immunosuppression on gene expression in HSV 1 latently infected mouse trigeminal ganglion. Invest Ophthalmol Vis Sci 2002; 43: 1862-1869.

20 Cook SD, Hill JH. Herpes simplex virus: molecular biology and the possibility of corneal latency. Surv Ophthalmol 1991; 36: $140-148$.

21 Keijser S, van Best JA, Van der Lelij A, Jager MJ. Reflex and steady state tears in patients with latent stromal herpetic keratitis. Invest Ophthalmol Vis Sci 2002; 43: 87-91.

22 Liesegang TJ. Classification of herpes simplex virus keratitis and anterior uveitis. Cornea 1999; 18: 127-143.

23 Holland J, Schwartz GS. Classification of herpes simplex virus keratitis. Cornea 1999; 18: 511-531.

24 Herpetic Eye Disease Study Group. A controlled trial of oral acyclovir for herpes simplex stromal keratitis. Ophthalmology 1994; 101: 1871-1882.

25 Barron BA, Gee L, Hauck WW, Kurmij N, Dawson CR, Jones $\mathrm{DB}$ et al. Herpetic eye disease study. A controlled trial of oral acyclovir for herpes simplex stromal keratitis. Ophthalmology 1994; 101: 1871-1882.

26 Herpetic Eye Disease Study Group. Acyclovir for the prevention of recurrent herpes simplex virus eye disease. N Engl J Med 1998; 339: 300-306.

27 Shwartz GS, Holland EJ. Oral acyclovir for the management of herpes simplex virus keratitis in children. Ophthalmology 2000; 107: 278-282.

28 Gordon JY. The evolution of antiviral therapy for external ocular viral infection over twenty-five years. Cornea 2000; 19: $673-680$.

29 Kaufman HE. Can we prevent recurrences of herpes infections without antiviral drugs? Invest Ophthalmol Vis Sci 2002; 43: 1325-1329.

30 Williams KA, Ash JK, Pararajasegram P et al. Longterm outcome after corneal transplantation: results and patient perception of success. Ophthalmology 1991; 98: 651-685.

31 Halberstadt M, Machens M, Gahlenbek K-A, Bohnke M, Garweg JG. The outcome of corneal grafting in patients with stromal keratitis of herpetic and non-herpetic origin. Br J Ophthalmol 2002; 86: 646-652.
32 Barney NP, Foster CS. A prospective randomised trial of oral acyclovir after penetrating keratoplasty for herpes simplex keratitis. Cornea 1994; 13: 232-236.

33 Kaye SB, Baker K, Bonshek R, Maseruka H, Grinfeld E, Tullo A et al. Human herpes viruses in the cornea. Br J Ophthalmol 2000; 84: 563-571.

34 Lomholt JA, Baggesen K, Ehlers N. Recurrence and rejection rates following corneal transplantation for herpes simplex keratitis. Acta Ophthalmol Scand 1995; 73: 29-32.

35 Larkin DFP. Corneal transplantation for herpes simplex keratitis. Br J Ophthalmol 1998; 82: 107-108.

36 Mannis MJ, Plotnik RD, Schwab IR, Newton RD. Herpes simplex dendritic keratitis after keratoplasty. Am J Ophthalmol 1991; 111: 140-484.

37 Biswas S, Suresh P, Bonshek RE, Corbitt G, Tullo AB, Ridgway AEA. Graft failure in human donor corneas due to transmission of herpes simplex virus. Br J Ophthalmol 2000; 84: 701-705.

38 Cockerham GC, Krafft AE, McLean IW. Herpes simplex primary in graft failure. Arch Ophthalmol 1997; 115: 586-589.

39 De Kessel RJ, Koppen C, Ieven M, Zeyen T. Primary graft failure caused by herpes simplex virus type 1. Cornea 2001; 20: 187-190.

40 Remeijer L, Maertzdorf J, Doorneubal P, Verjans GMGM, Osterhaus ADME. Herpes simplex virus 1 transmission through corneal transplantation. Lancet 2001; 357: 442.

41 Neufeld MV, Steinmann TL, Merin LM, Strop WG, Brown MF. Identification of a herpes simplex virus-induced dendrite in a eye-bank donor cornea. Cornea 1999; 18: 489-492.

42 Sengler U, Reinhard T, Adams O, Krempe C, Sundmacher $\mathrm{R}$. Herpes simplex virus infection in the media of donor corneas during organ culture: frequency and consequences. Eye 2001; 15: 644-647.

43 Remeijer L, Maertzdorf J, Buitenwerf J, Osterhaus AD, Verjains FM. Corneal herpes simplex virus type 1 superinfection in patients with recrudescent herpetic keratitis. Invest Ophthalmol Vis Sci 2002; 43: 358-363.

44 Shimeld C, Tullo AB, Easty DL et al. Isolation of herpes simplex virus from the cornea in chronic stromal keratitis. Br J Ophthalmol 1982; 66: 643-647. 